Accepted manuscript (AAM)

Published version available at: https://doi.org/10.1080/13629387.2019.1702532

Zuzana Hudáková (2019) "Civil society in Tunisia: from islands of resistance to tides of political change," The Journal of North African Studies, DOI: 10.1080/13629387.2019.1702532.

\title{
Civil Society in Tunisia: From Islands of Resistance to Tides of Political Change
}

Zuzana Hudáková a, b (https://orcid.org/0000-0003-0542-3574)

${ }^{a}$ Center for International Studies (CERI), Sciences Po, Paris, France;

${ }^{\mathrm{b}}$ Department of International Relations and Political Science, The Graduate Institute, Geneva, Switzerland

The role of civil society as a democratising force both under authoritarian regimes and during political transitions has received renewed attention in the wake of the 'Arab Spring' uprisings. Considerable praise has been reserved for Tunisia, whose civil society played a prominent role in the country's successful transition. However, as a thorough analysis of the Tunisian example illustrates, this contrasts sharply with its relatively marginal role in the pre-2011 period. Indeed, Tunisian civil society has not always been a pro-democracy force, its functions shifted with the political context, and different types of civil society organisations (CSOs) played widely different roles. Tracing the evolution of civil society in Tunisia from the establishment of the Ben Ali regime in November 1987 until after its fall in January 2011, the article develops a more nuanced and dynamic understanding of its roles before, during, and after the revolution. More specifically, it shows that before the revolution, only a handful of CSOs served as islands of political resistance, while the majority functioned as vehicles of regime resilience, helping to strengthen authoritarian rule in the country. During the revolution, members of more critical CSOs played an important supporting role in the spread, organisation, and continuation of protests. Finally, in the postrevolutionary period, former oppositional CSOs, together with a plethora of newly created CSOs, were crucial not only in successfully steering the country towards a democratic transition but also in strengthening the nascent democracy. Civil society should thus be understood in its variety and particular political context.

Keywords: civil society; Tunisia; authoritarianism; democratisation; transition 


\section{Introduction}

The revolution in Tunisia, which brought an end to the more than 23 year-long authoritarian rule of Zine El Abidine Ben Ali, is often celebrated as the only success story of the 'Arab Spring' uprisings. Although the country continues to face important political, economic, social, and security challenges, it has significantly expanded the social and political freedoms enjoyed by the population and proceeded to hold two rounds of free and fair elections, prompting its classification as the first and only Arab democracy in 40 years (Freedom House 2015). Civil society organisations (CSOs) are widely perceived to have played an important role in the country's successful political transition. They not only actively participated in the various transitional mechanisms put in place following the departure of President Ben Ali on 14 January 2011 and contributed to the drafting of the country's first democratic constitution, but also repeatedly stepped up their political role during times of political crisis.

Most notably, four prominent CSOs launched a 'National Dialogue' initiative to act as mediators during the 2013 political impasse that threated to derail the Tunisian political transition following the successive assassinations of two left-wing opposition figures. Successful in steering the country back on track at a time of heightened Islamist-secular polarisation, the initiative was awarded the 2015 Nobel Peace Prize 'for its decisive contribution to the building of a pluralistic democracy in Tunisia in the wake of the Jasmine Revolution of 2011' (Norwegian Nobel Committee 2015). Three of the organisations - the Tunisian General Labour Union (Union générale tunisienne $d u$ travail, UGTT), the Tunisian League for Human Rights (Ligue tunisienne des droits de l'homme, LTDH), and the Tunisian Bar Association (Ordre national des avocats de Tunisie, ONAT) - enjoyed substantial symbolic capital for their role as rare voices of opposition during the Ben Ali regime. ${ }^{1}$ In the absence of a viable, mutually acceptable 
political alternative capable of breaking the deadlock, they were able to successfully mediate among the various political actors. Coming at a time of profound civil society disillusionment with government policies and societal disappointment at the lack of progress on the socio-economic grievances that had helped spur the revolution, the Noble Peace Prize was not only 'intended as an encouragement to the Tunisian people' but also as a general recognition that 'civil society institutions and organisations can play a crucial role in a country's democratisation, and that such a process, even under difficult circumstances, can lead to free elections and the peaceful transfer of power' (Norwegian Nobel Committee 2015).

The democratizing capacity of Tunisian civil society after the revolution contrasts sharply with the pre-2011 situation, when Tunisian CSOs overwhelmingly contributed to the resilience of the Ben Ali regime. Although a handful of human rights and women's organisations, general unions, and professional associations were able to maintain a certain degree of autonomy vis-à-vis the regime, they presented but small islands of resistance in a sea of co-opted organisations. Unable to bring about political change, they were nonetheless essential in sustaining opposition in the authoritarian context, as well as in preparing the ground to serve as important supporting actors during the revolution and as leading actors during the subsequent democratic transition.

Arguing for a more differentiated view of CSOs and their role in democratisation, this article traces the changing roles played by Tunisian civil society over time, from 1987 until the present. To this end, it proceeds in four steps. The following section revisits the literature on the democratising role of civil society across different political settings and specifies the relevant dimensions of analysis. Section three investigates the dual role played by Tunisian civil society before the revolution, both as vehicles of regime resilience and as important islands of political resistance. It 
explores the variety of methods used by the regime to co-opt and constrain civil society activity as well as the trajectories of the three types of more critical CSOs during the authoritarian rule of Ben Ali: human rights and women's organisations, general unions, and professional associations. Section four focuses on the changing role of the more critical CSOs before, during, and after the revolution, as they developed from small islands of resistance to tides of political change helping to steer the country on the path to democracy. The article concludes by drawing implications from the Tunisian case for our understanding of civil society in authoritarian regimes more generally.

\section{Civil society: A democratising force?}

Civil society ${ }^{2}$ is often implicitly or explicitly assumed to possess an inherently democratising potential, either helping to strengthen existing democracies or bring down non-democratic regimes (Folley and Edwards 1996). In established democracies, participation in even apolitical associations is believed to foster civility (Tocqueville 1835) and develop social capital (Putnam 1993, 2000), crucial for the practice of democracy. In non-democratic countries, more independent CSOs are frequently seen as viable alternatives to weak political parties (Langohr 2004). Based on the experiences with democratisation in Latin America (O’Donnell and Schmitter 1986) and Eastern Europe (Michnik 1985; Bernhard 1993; Diamond 1994), civil society in authoritarian settings is often credited with the ability to democratise the society from below, counterbalance the regime, or push it to progressively democratise. A dense network of civil society associations, especially those organised horizontally and cutting across societal cleavages, is thus widely considered to present not only an important impetus for democratisation but also a necessary component for the successful consolidation of democracy (Diamond 1994; Hadenius and Uggla 1996; Linz and Stepan 1996). Applying these insights to authoritarian, semi-authoritarian, and newly democratic 
regimes around the world, support for CSOs has become one of the core elements of democracy promotion strategies (Carothers 1999).

However, the validity of the association between civil society and democratisation has been questioned both theoretically and empirically. For one, civil society need not always strengthen, but can also undermine democracy. This was the case, for example, in the interwar period, when 'civil' CSOs facilitated the rise of rightwing regimes across Europe (Berman 1997; Riley 2010), but a variety of 'uncivil' CSOs with non- or anti-democratic orientation routinely operate not only in authoritarian regimes (Rahman 2002), but also in new (Kopecky and Mudde 2003) and established (Ruzza 2009) democracies. Nor is thriving civil society necessarily associated with successful democratic consolidation, as illustrated by the comparative analysis of associational life in Spain and Brazil (Encarnación 2003). In fact, mandatory participation in CSOs during the authoritarian period had a significant long-term demobilizing effect not only in post-Franco Spain, but also in post-Communist Europe (Howard 2003), and a history of past anti-regime civil society activism in Latin America actually resulted in a legacy of mistrust and anti-state attitudes that helped undermine the newly created democratic institutions (Armony 2004). For another, civil society's ability to democratise authoritarian regimes seems to have been seriously overstated. On the one hand, the importance of civil society during the 'third wave' of democratisation (Huntington 1991) has been re-evaluated as largely exaggerated in both Eastern Europe (Tempest 1997; Kotkin 2010) and Latin America (Grugel 2000). On the other hand, historical research into $18^{\text {th }}$ and $19^{\text {th }}$ century associational life in Latin America (Forment 2003) showed that vibrant associational life need not result in a democracy but can also encourage individuals to turn away from politics, decreasing the overall chances of successful democratisation. 
In fact, civil society is routinely found to strengthen, rather than undermine, authoritarian regimes in a wide range of non-democratic contexts, including the Middle East and North Africa (MENA) region (Schlumberger 2000; Yom 2005, Heydemann 2007). As a result, much of the recent literature on civil society in authoritarian regimes is critical of the democratising potential of CSOs in authoritarian settings (Lewis 2013), questioning the role of democracy promotion in supporting democracy (Powel 2009; Challand 2011; Pikulik and Bedford 2019), as well as the ability and willingness of CSOs to oppose the authoritarian regimes in which they operate. In this respect, the cooperative relations between CSOs and authoritarian regimes observed in a variety of contexts, from MENA (Clark 2013) to China (Hsu 2010; Spires 2011) and Central Asia (Ziegler 2010), are frequently shown to be relatively 'symbiotic' - that is, mutually beneficial and largely voluntary - rather than a result of coercion alone. In particular, CSOs can gain access to state resources, work towards shared goals, or provide input for limited political reforms, while authoritarian regimes are able to outsource some of their functions, including social control (Wiktorowicz 2000), and present themselves as pluralistic and inclusive, increasing their legitimacy both domestically and internationally. This is true not only for government-organised non-governmental organisations, or GONGOs (Heydemann 2007; Durac and Cavatorta 2009), and standard CSOs like labour unions (Clark 2013), but also critical members of professional associations (Repnikova 2018) and unrecognised grassroots nongovernmental organisations (Spires 2011). Moreover, even secular, pro-democracy, liberal, oppositional civil society - which much of the literature on democratisation seems to have in mind - can have 'uncivil' tendencies, such as contributing to the exclusion and repression of other civil society actors (Rahman 2002), reproducing elements of the larger authoritarian context within its structures (Jamal 2007), or 
promoting 'elite interests' at the expense of 'those of ordinary citizens' (Doyle 2016, 403).

If civil society has the capacity to both strengthen and weaken political regimes, then contextual factors, such as the particular political setting, type of CSO, and composition of civil society at any given moment, as well as CSOs' relationship with the regime and each other, are crucial in understanding their positive or negative impact on (the prospects of) democratisation. The role of civil society, including its particular subcomponents, is thus also unlikely to be stable over time and across different political contexts. For instance, Diamond $(1994,7)$ argues that a 'vibrant' civil society might be more important 'for consolidating and maintaining democracy than for initiating it', while Fishman $(2017,405)$ suggests that civil society's role in democratisation is heavily influenced by the mode of transition and is therefore "not easily predictable on the basis of patterns of social organisation or mobilisation under late authoritarian rule or even in the initial stage of political change'. If civil society is inherently neither pronor anti-regime, pro- nor anti-democratic, and its role varies over time, its particular function in a given context should be examined, rather than assumed.

In order to analyse the changing roles of CSOs in Tunisia, I adopt a neutral conception of civil society, both in terms of the goals pursued by the individual organisations as well as their internal practices. Including both 'civil' and 'uncivil' actors, I also relax the condition of civil society autonomy from the state. Unrealistic even in democracy, it is virtually unattainable in authoritarian settings given the regimes' reliance on a strong coercive apparatus, as well as a variety of legal and extralegal measures, to either co-opt or constrain organised challenges to their rule. Including the full spectrum of CSOs also allows to distinguish between the roles different CSOs play vis-à-vis the regime, both as supporters and challengers of the regime. In this 
paper, I focus specifically on three types of CSOs that managed to maintain a certain degree of autonomy from the Ben Ali regime during the authoritarian period: (1) human rights and women's organisations, (2) general unions, and (3) professional associations, each with different characteristics, membership, and mobilisation potential.

In what follows, I examine the dual role played by civil society in Tunisia from the establishment of the Ben Ali regime in November 1987 until the beginning of antiregime protests in December 2010, before tracing the changing role of the more critical CSOs before, during, and after the revolution in section four. The resulting analysis is based on available reports by human rights organisations as well as extensive fieldwork in the country, undertaken between 2014 and 2016, which included semi-structured interviews with 70 members of Tunisian CSOs at both rank-and-file and leadership positions. Distributed relatively equally between those in their 20s (31.4\%), 30s (28.6\%), and older $(21.4 \%$ in their $40 \mathrm{~s}$ and $18.6 \%$ in their $50 \mathrm{~s}$ or $60 \mathrm{~s})$, the interviewees included more than a third of women (37.1\%) and an equal portion of individuals from outside of the capital, two groups whose views tend to be severely underrepresented. Overall, the focus has been primarily on understanding the experiences of individuals active in the more critical CSOs during the authoritarian period, but they - together with several members of pro-regime CSOs, as well as newly created CSOs - were also interviewed about the revolution and the development of Tunisian civil society in the post-revolutionary period.

\section{Tunisian civil society under Ben Ali (1987 - 2010)}

At the time of the revolution, almost 10,000 associations were officially registered in Tunisia, ${ }^{3}$ four times as many as when President Ben Ali took power on 7 November 1987 (see Figure 1 below). The associational boom took place mostly in the first two years, when the existing Associations law was relaxed ${ }^{4}$ and the regime pursued more 
democratic policies in an effort to distinguish itself from the increasingly authoritarian rule of former 'President for life' Habib Bourguiba. In the changed political climate, a number of more independent CSOs and political parties were legalised and several leading opposition members were incorporated into state structures.

[Figure 1]

However, the political opening was short-lived. The regime began to crackdown on the Islamists in 1989 and, after it virtually eliminated them on Tunisian soil in the early 1990s, turned its attention to other opponents, including from amongst the civil society. Many of the liberalizing reforms were reversed, censorship was reintroduced, and the Associations' law amended to restrict CSOs' operation. ${ }^{5}$ In the increasingly repressive environment, critical voices were muted. New, more oppositional CSOs were denied recognition, while most existing CSOs adopted a more cautionary approach or a directly pro-regime line in order to be able to continue their work. ${ }^{6}$ Although the regime reverted to more authoritarian forms of governance, it continued to promote the illusion of Tunisia's pluralism and respect for human rights both at home and abroad. ${ }^{7}$

More vocal criticism by the regime's opponents as well as the general population began to re-emerge only in the late 1990s and early 2000s. The period saw the creation of a number of new illegal organisations, resurgence of more critical positions within some of the existing CSOs, as well as a search for greater autonomy from the state by several established professional associations. However, their number and impact remained limited and they faced a strong backlash from the regime.

\subsection{Civil society as vehicles of regime resilience}

The lack of democratizing potential of the Tunisian civil society during the authoritarian 
period was largely the result of a dual strategy pursued by the Ben Ali regime. On the one hand, the regime used a variety of legal and coercive measures to constrain and prosecute any organisation that engaged in critical discourse or refused to accept its control. On the other hand, it actively created and co-opted CSOs to act as instruments of social control and distribution of privilege, helping to maintain its power. The specific mix of coercion and co-optation not only restricted the ability of CSOs to openly challenge the regime but also significantly decreased their willingness to do so. As a result, the large number of CSOs in Tunisia, and any dissenting voices present within them, were effectively managed by the regime or its representatives and individual CSOs continued to exist largely because they posed little threat, operated within the space delimited by the regime, and helped it fulfil a particular purpose. The two strategies are explored in greater detail below.

\subsubsection{Constraining opposition}

Operating in a highly restrictive legal and political environment, the space for action and ability of CSOs to work independently of the state were severely curtailed both in law and practice. As a result, the vast majority of Tunisian associations created throughout the period were active in ostensibly unpolitical areas like arts and culture, education, or sports (Foundation for the Future 2013, 8; UNDP 2014, 11), while critical pro-democracy organisations, which presented only a small minority of CSOs, possessed limited domestic visibility and mobilisation potential.

Formally, the restrictive legal framework governing associations ${ }^{8}$ provided the regime with substantial discretion in granting CSOs legal recognition and imposed various restrictions on their everyday operation. Officially operating under a declaration system, whereby an organisation was legally constituted at the end of the legally mandated period in the absence of rejection from the Ministry of Interior, ${ }^{9}$ the 
responsible authorities often refused to accept the application or failed to issue a receipt confirming the filing of the application, leaving the organisations without a proof or ability to legally challenge the decision. Associations were also required to specify, and subsequently constrain, their goals and activities to one of eight categories: (1) women's; (2) sports; (3) scientific; (4) cultural and artistic; (5) charitable, relief, and social; (6) development; (7) friendship; and (8) general character associations. ${ }^{10}$ Two types of more problematic CSOs also faced additional provisions restricting their operation. Charitable organisations, many of which were religious in character, were not allowed to accept donations without an approval by the Ministry of Interior, ${ }^{11}$ while general character associations were prohibited from having political party leaders in prominent positions within the association and from refusing membership to anyone formally committed to their principles. ${ }^{12}$ The latter provision, specifically targeting the vocal LTDH, allowed the state to flood the organisation with pro-regime supporters, paralyze its activities, and entangle it in legal battles.

The regime also maintained de facto control over associations' financing. This was done either directly - by requiring approval of donations, providing parts of associations' budgets, and managing transfers from public employers' salaries - or indirectly, by maintaining the power to block transfers from international sources via the Tunisian Central Bank. Given the various restrictions on the acceptance of subsidies, donations, and foreign funding, the Tunisian state was the primary source of income for many organisations, further limiting their ability and willingness to challenge the regime and act as an effective counter-balance to its power. Any public meetings and events also required official authorisation, ${ }^{13}$ which was withheld from the more independent CSOs that also frequently had their regular meetings disrupted and their premises closed off by the police. The maintenance of foreign relations was also 
eventually criminalised. ${ }^{14}$ As a result of such restrictions, a number of more critical or independent-minded organisations were either not officially legalised or forced to restrain their criticism to secure their continued operation, meaning that, at one point, virtually every legal organisation - including the more critical ones - had to compromise with the regime in one way or another. As a result, a 'division of labour' sometimes took place between the less critical legal and more critical illegal CSOs (Weilandt 2019: 962-3).

Informally, the regime also sought to limit the autonomy of existing CSOs from within, by relying on regime supporters within the ranks of the organisation and their recourse to legal action. In the first place, regime supporters in virtually any type of $\mathrm{CSO}$, including unions and professional organisations, tried to ensure that pro-regime candidates were elected to the CSO's leadership. If this was not successful, they challenged the results through petitions, extraordinary congresses, and accusations of procedural irregularities to organise new elections whose legality and results were subsequently upheld by the courts. In this way, independent boards were removed and replaced by pro-regime leadership, official strike decisions were judicially invalidated, organisations' offices closed, and congresses prevented from taking place, while legal challenges against such decisions remained largely unsuccessful. This allowed the regime to claim no responsibility for the outcomes of what it insisted were 'internal associational affairs'. As the plethora of accounts collected by human rights organisations like Amnesty International or the Human Rights Watch document, prominent civil society activists were also targeted individually with professional consequences and politically motivated trials. Judges pronounced harsh sentences to a routine set of charges such as spreading false information, disturbing the public order, defaming the authorities, belonging to an unauthorised or criminal organisation, and 
holding unauthorised meetings. Alternatively, prosecution involved unrelated, trumpedup charges, like damaging property, verbally and physically abusing a police officer, possession of narcotics, or violation of public decency. Critical civil society activists and their families also faced intense smear campaigns, surveillance, harassment, limits on the freedom of movement, destruction or confiscation of property, arbitrary arrests, and verbal or physical attacks. ${ }^{15}$ Demonstrating the strength and resilience of the Ben Ali regime, such punishments were meant not only to exert pressure on those criticising the regime but also to serve as a warning to others, further limiting the size of the opposition.

\subsubsection{Promoting loyal civil society}

While limiting the operation of specific CSOs, the Ben Ali regime simultaneously encouraged the development of civil society in general and loyal CSOs in particular. The thriving civil society was then used as an instrument of social control and distribution of privilege domestically, as well as a façade of democracy and pluralism internationally, helping the regime to both maintain power and further its political objectives. Besides making use of the various restrictions, the regime actively sought to create and maintain the support of the different CSOs by granting them privileged access and distributing benefits to their members. Loyal CSOs could count on direct state funding, while professional organisations often had a party cell (khaliyya) that helped their members advance at work, get selected for travel, or secure access to public sector clients. ${ }^{16}$ Since 2005 , representatives of the most prominent national organisations were also present in the second chamber of the Parliament, further decreasing their incentive to seek greater institutional autonomy. ${ }^{17}$

Overall, the regime sought to maintain the image of unity and consensus through a corporatist approach to governance conductive to civil society co-optation. CSOs that 
helped promote the regime's agenda were incorporated into the party-state, drawn upon by the respective Ministries, their activities were publicly funded, and their representatives enjoyed diverse benefits including official representation of the country in international forums. In return, they were routinely called upon to show support for the regime by mobilizing their members for elections, participating in ruling-party rallies, and spreading a positive image of the regime. Loyal organisations were sometimes granted a virtual monopoly in their field and many were in practice transformed into an extended arm of the state. This was the case with the National Union of Tunisian Women (Union national de la femme tunisienne, UNFT), a 180,000member strong association that was used by the regime to push aside its much smaller independent alternative, the Tunisian Association of Democratic Women (Association tunisienne des femmes démocrates, ATFD), as well as with the formally independent Tunisian Union of Social Solidarity (Union tunisienne de solidarité sociale, UTSS), which acted as the de facto coordinator for charity organisations in the country. Together with the state-run National Solidarity Fund, which collected 'voluntary' contributions from private citizens as well as the public and private sector, ${ }^{18}$ the UTSS helped to keep Islamic charity organisations - so widespread elsewhere in the region uninvolved. The most prominent regime supporters that took part in the nationalistcorporatist logic of associational life under Ben Ali, like the UNFT, could also seek recognition as 'national interest' associations. ${ }^{19}$

As a result of the various restrictive and co-opting measures, cooperation with the regime presented a pragmatic way for many organisations to not only continue their activities but also obtain the necessary means and opportunities to do so. Maintaining a pro-regime line was a price they were willing to pay. In some cases, the pragmatism gave way to a relatively 'symbiotic relationship', found also in other authoritarian 
contexts (Spires 2011; Clark 2013). This was true for the UGTT as well as some professional associations. Others cooperated because they shared some of the regime's goals, including improving the situation of women, alleviating poverty, or developing the country's marginalised regions. Indeed, even the more critical and independent secular CSOs, like the ATFD, accepted government funds or did not oppose government persecution and marginalisation of the Islamists, whom they tended to see as worse than the regime. ${ }^{20}$ Given the multiple fault lines running through the society and differing opinions among CSOs on cooperation with the regime, the regime was able to make use of a 'divide and conquer' strategy, keeping the loyal organisations dependent and the more rebellious ones weak and fragmented.

The regime also actively established organisations intended to counter the influence of more independent CSOs both at home and abroad by formally appropriating opposition concerns and acting as rival organisations to specific critical CSOs. In the field of human rights, this was the case with the Higher Committee on Human Rights and Fundamental Freedoms, created in 1991 to counter the influence of the outspoken LTDH. Many of such GONGOs or co-opted CSOs received foreign funding and support through democracy promotion or were officially included in consultations with foreign governments and international organisations, including the United Nations. This not only helped strengthen and legitimate the Ben Ali regime (Durac and Cavatorta 2009) but also developed the social capital of pro-regime groups at the expense of more independent actors. Often, the existence of such organisations was mostly formal.

Existing CSOs were also used as means of socio-political control, extending political surveillance beyond the ruling party and the state security apparatus. Indeed, regime supporters were present in virtually all formal organisations, ensuring pro- 
government rhetoric and guarding against their take-over by critical or independentminded individuals. As a result of the various co-opting and restrictive measures, almost all CSOs in Tunisia were actively or at least formally loyal to the regime. Last but not least, the existence of a large number of CSOs, regardless of their activity or relationship with the state, helped foster an image of democratic pluralism, which together with the country's support of the US-led 'global war on terror', exemplary application of World Bank and International Monetary Fund-promoted neo-liberal economic policies, and strong legal standing of women - helped alleviate some of the international criticism of the regime.

\subsection{Civil society as islands of political resistance}

Although the vast majority of CSOs prior to the revolution were at least formally loyal to the regime, a handful of relatively independent CSOs was able to maintain a certain margin of autonomy vis-à-vis the state and pursue a more critical line towards the regime. They consisted of a small number of human rights and women's organisations, general unions, and professional associations, supported by Tunisian and international organisations operating abroad. ${ }^{21}$ These CSOs not only had relatively strong ties with each other but there was also a certain degree of overlap between them. As a civil society and political activist from Gafsa explained, 'You will find the same members in Amnesty International, the Tunisian Human Rights League, the Tunisian General Labour Union, and the Progressive Democratic Party... the same people in the meetings, the same vision... We didn't leave an empty space. ${ }^{22}$ While the majority of these organisations were officially recognised, some operated in 'semi-illegality' whereby the regime knew about their existence, controlled their offices, and tolerated some of their activities but simultaneously kept their members under constant threat of prosecution for illegal activity, fining, imprisoning, and cracking down on them as it 
saw fit.

Despite the various coercive pressures and legal limits on their operation, these organisations were able to act as important political alternatives and rare voices of opposition to the regime during the authoritarian period. In what follows, I explore the different forms of contestation that took place within the three main types of more critical CSOs in Tunisia - human rights and women's organisations, general unions, and professional associations - to highlight the limits as well as the possibilities of civil society opposition in authoritarian settings.

\subsubsection{Human rights and women's organisations}

During the Ben Ali period, members of human rights and women's organisations were not only among the most targeted political opponents but also the most vocal domestic critics of the Ben Ali regime. ${ }^{23}$ The most prominent amongst them was the LTDH, the Arab world's oldest human rights organisation. In the words of Ali Zeddini, the organisation's Vice-President, 'The LTDH was the principal organisation of resistance during the regime of Ben Ali, playing the role of the opposition and perceived as enemy number one by the regime... We had a network and knew how to resist. ${ }^{24}$ This was true especially during the early years of the Ben Ali regime, when it was one of the only voices opposing the regime's brutal crack-down on the Islamists. As a result, it was specifically targeted and progressively paralyzed by the regime. In 1998, frustration with the largely subjugated LTDH led to the creation of a more critical National Council for Liberties in Tunisia (Conseil national pour les libertés en Tunisie, CNLT). Regrouping a large number of prominent regime opponents across the political spectrum as well as several more critical LTDH members, it was denied legal recognition. The LTDH re-entered the opposition scene in 2000, after electing a more independent and outspoken executive committee. However, due to legal challenges of 
the election results from some of its pro-regime members, it operated in an ambiguous legal state and faced severe restrictions on its activities. ${ }^{25}$

The two broad-coalition organisations were subsequently joined by two smaller, more partisan human rights organisations, the International Association for the Support of Political Prisoners (Association internationale de soutien aux prisonniers politiques, AISPP) and the Association for the Fight against Torture in Tunisia (Association de lutte contre la torture en Tunisie, ALTT), neither of which were legalised. The former was created in 2002 and regrouped primarily Islamist sympathizers, while the latter was created in 2003 and was composed mainly of lawyers with leftist tendencies, although its members regularly defended Islamists as well. ${ }^{26}$ Unlike the larger organisations, which took a more general advocacy approach, they focused specifically on providing support and legal assistance to individuals prosecuted or otherwise mistreated by the regime. $^{27}$

A small number of other independent CSOs with issue-specific agendas also managed to maintain a critical position vis-à-vis the regime. The most prominent among them was the ATFD, which together with the Association of Tunisian Women for Research and Development (Association des femmes tunisiennes pour la recherche sur le développement, AFTURD) regrouped a limited circle of mostly secular leftist feminists from the coastal regions, ${ }^{28}$ who presented an independent counter-pole to the much larger, pro-regime UNFT. Like other legal CSOs, the ATFD had a somewhat ambiguous relationship with the regime throughout the 1990s, accepting state funding and conditions on its activity and tacitly supporting the regime's crackdown on the Islamists, ${ }^{29}$ but it re-emerged as more critical in the 2000s. Throughout the decade, its members - like those of the human rights organisations - participated in sit-ins and unauthorised protests and the organisation issued regular communiqués and cooperated 
on anti-regime campaigns with the other oppositional forces in the country on a caseby-case basis. In 2008, the ATFD played an important role in supporting the families of those prosecuted for their participation in the Gafsa mining basin protests and, the following year, it launched its own Feminist University, which it was forced to shut down after the organisation's participation in the 2009 election report by independent Tunisian CSOs, including the LTDH and CNLT. ${ }^{30}$ While the ATFD and AFTURD were legalised during the period of political liberalisation following Ben Ali's ascension to power, newer, more critical civil society initiatives were unable to secure legal recognition.

\subsubsection{General unions}

The general unions in Tunisia presented a mixture of broader, mass-based institutions and more partisan, smaller organisations. With over half a million members, the UGTT, Tunisia's sole trade union federation, presented the country's oldest and most important national organisation. A sui generis actor that was 'more than a classical labour union and something else than a party' (Yousfi 2015, 241), it played a prominent political role throughout Tunisian history. For many, the two aspects were deeply intertwined. As a former political prisoner active during the 2008 Gafsa uprising remarked, 'You cannot be unionist without politics and you cannot do politics without unionist work. ${ }^{31}$ Regrouping members with various political tendencies and social backgrounds, the UGTT oscillated between periods of close alignment with the state and the ruling party and periods of confrontation and search for greater autonomy (Yousfi 2015).

Although the union's leadership continued to support the regime throughout the Ben Ali period, it occasionally pushed back against its decisions in the 2000s. This was the case most prominently in 2005 , when the union boycotted the newly created second chamber of the Parliament over its insufficient representation in the body and helped 
organise protests against the Israeli Prime Minister's participation in the World Summit on the Information Society held in Tunis. ${ }^{32}$ Most oppositional activity, however, took place on the lower organisational levels. Although the overall number of active regime opponents within the organisation unlikely surpassed 10 percent, ${ }^{33}$ UGTT members participated in unauthorised strikes and supported various collective and individual challenges to the regime, while the organisations' premises presented not only the sites but also the points of departure for virtually all protests during the decade. ${ }^{34}$

Occasionally, these members also tried to push the higher ranks towards more confrontational stance vis-à-vis the regime. However, such attempts were mostly unsuccessful.

The double role of the organisation was facilitated by the union's complex organisational structure of local, regional, and national levels with cross-cutting sectoral federations (Yousfi 2015). ${ }^{35}$ This enabled resistance to continue at the grassroots levels even during times when the union's leadership was particularly close to the regime, leading some to speak of 'two UGTTs' (Chouikha and Geisser 2010). The most prominent example of the competing dynamics was the organisation's reaction to the 2008 Gafsa uprising - the most serious pre-2010 challenge to the Ben Ali regime which was supported by local union structures but opposed by the regional as well as the national leadership (Allal 2008). Although the leadership did not change its position vis-à-vis the uprising or its most vocal supporters within the union despite significant pressure from below, many UGTT members came to increasingly regard the leadership's approach as wrong, which significantly influenced their positions towards future regime challenges. ${ }^{36}$

Unlike the UGTT, the General Union of Tunisian Students (Union générale des étudiants de Tunisie, UGET) was comprised mostly of left-leaning students and stood in 
open competition with the pro-regime student association. Significantly smaller, UGET regrouped only a limited number of students, with estimates of its most active members ranging between 1 and 2.5 percent of the student body. ${ }^{37}$ Nonetheless, the union maintained a visible presence in many universities and regularly managed to mobilise a substantial number of students in response to both university-related and international political issues. The strongest UGET faculties were also able to secure a significant portion of the student seats in university elections to the Scientific Councils, the main point of contention between the two student unions. ${ }^{38}$ While many of UGET activities, such as agitations, university clubs, protests, and sit-ins, were related to the defence of student issues and thus within the scope of unionist work, they frequently also had an openly political dimension. ${ }^{39}$

Unlike the two established unions, the Union of Unemployed Graduates (Union des diplômés chômeurs, UDC), whose newest reincarnation was created in mid-2000s by a number of former UGET activists, ${ }^{40}$ was repeatedly denied legal recognition. Yet, by making use of their pre-established contacts, its members developed a network of committees in different parts of the country that operated primarily locally. ${ }^{41}$ Their activities included hunger strikes, sit-ins in front of local governorate buildings, the distribution of flyers popularizing their cause, as well as symbolic acts - such as trying to sell one's university diploma at the central market for 100 millimes (less than 10 Euro cents at the time) - serving as a commentary on the value of an advanced degree in an economy that had several thousand fewer jobs than university graduates annually. ${ }^{42}$ Since the organisation was repeatedly denied legal recognition, it sought refuge within oppositional parties and CSOs with legal structures - especially the UGET and UGTT.

\subsubsection{Professional associations}

After a general submission to the regime throughout the 1990s, the 2000s witnessed 
mounting criticism also among some of the country's professional associations. The increasingly vocal opposition to Ben Ali's authoritarian practices was not only a result of the presence of regime opponents within these structures, but also a reflection of a more general demand for greater organisational autonomy among the rank-and-file members. This sentiment was echoed by a prominent Tunisian journalist, civil society, and political activist Naziha Réjiba in her International Press Freedom Award acceptance speech, when she insisted that she was 'neither a hero nor a victim, but a journalist who wishes to work under normal conditions' (Committee to Protect Journalists 2009).

Throughout the 2000s, the strongest opposition came from the lawyers and, to a lesser degree, also from journalists and judges. ONAT entered into more open confrontation with the regime after declaring a general strike - the first one in a decade - in April 2000 in reaction to police aggression against lawyers attempting to visit a prominent regime opponent during his hunger strike. Further mobilisations ensued, both in response to specific regime transgressions against lawyers and as a result of professional concerns. ${ }^{43}$ For example, in 2002, lawyers went on strike in response to a particularly unfair conduct of a political trial with illegal political party members. ${ }^{44}$ In 2005, a group of anti-regime lawyers across the political spectrum created an independent committee to support a lawyer sentenced for publishing an article critical of the regime, which eventually succeeded in persuading ONAT to call an organisationwide sit-in, despite initial opposition from the leadership. ${ }^{45}$ A year later, the Bar President and the majority of ONAT Council members undertook a 48-hour strike against proposed changes that would decrease the organisation's control over its membership. ${ }^{46}$ Throughout the decade, lawyers also eschewed pro-Ben Ali candidates for Bar President, who did not bring the desired professional advancements in the 
1990s, and increasingly condemned the regime's practice of professional privilege distribution through a ruling party cell (khaliyya) in an attempt to achieve more independence from the regime (Gobe and Ayari 2007; Gobe 2010, 2013).

Similarly, in 2004, a group of journalists tried to achieve greater professional autonomy by forming an independent Union of Tunisian Journalists (Syndicat des journalistes tunisiens, $\mathrm{SJT}$ ) to distinguish themselves from the heavily pro-regime Association of Tunisian Journalists (Association des journalistes tunisiens, AJT). Originally supported by 160 journalists, which presented about one fifth of accredited journalists, ${ }^{47}$ its membership was reduced to a handful of individuals after the regime expressed its opposition and the UGTT withdrew its offer to house the association. ${ }^{48}$ Nonetheless, the SJT continued to operate and the organisation enjoyed support of the International Federation of Journalists, which put substantial pressure on the regime to formally recognise the organisation. The professional schism was not resolved until 2008 when the AJT was dissolved and replaced by the National Union of Tunisian Journalists (Syndicat national des journalistes tunisiens, SNJT), which the SJT subsequently joined. The resulting organisation was more critical, but the relative professional autonomy was short-lived. ${ }^{49}$ The following year, journalists close to the regime organised an extraordinary congress where the more critical SNJT leadership was replaced by a pro-government executive committee.

A similar fate befell also the Association of Tunisian Judges (Association des magistrats tunisiens, ATM) after it had called for greater judicial independence and publicly criticised government interference in the judiciary in 2005. In a move akin to that made against the journalists, a group of 183 pro-regime judges, helped orchestrate another election. ${ }^{50}$ In its aftermath, the critical members were dismissed, demoted, or re- 
assigned to remote locations and the organisation was placed back into regime's hands. $^{51}$

\section{The changing role of more critical CSOs in Tunisia}

Over the past three decades, Tunisian civil society underwent a significant transformation. During the authoritarian period, the tightly controlled civil society was used primarily to prop up the regime. Organisations with mass membership were mobilised by the regime for propaganda purposes, while non-political and small, 'hollowed out' CSOs with largely formal existence were used to create an illusion of freedom and democracy. After the fall of the Ben Ali regime, civil society became much more diverse. Although some CSOs focused specifically on addressing the plethora of issues facing the country during the political transition, others sought to fulfil more narrow associational purposes. While the CSOs that managed to play a more critical role during the Ben Ali period continued to be important, their particular roles transformed with the changing political settings. In what follows, I trace the developments in the three types of more critical CSOs before, during, and after the revolution of 14 January 2011.

\subsection{Islands of resistance: Tunisian civil society before the revolution (1987-} 2010)

During the authoritarian rule of Ben Ali, associational life, like the public and private spheres themselves, was tightly controlled, allowing for little anti-regime opposition. Where resistance persisted, it was kept relatively minor and invisible to the broader society. The handful of CSOs opposing the regime throughout the period thus presented but islands of resistance in a sea of co-opted organisations. However, the challenges taking place within the civil society were particularly important because political parties 
throughout the region were weak, divided, and had a limited space for action (Langohr 2004).

While most people were interested in civil society work in its own right, many used CSOs as a way to engage in politics, blurring the lines between the two. Indeed, many considered their civil society activity to be political and a significant number of CSOs' members belonged to political parties or had close relations with them, while the organisations themselves were sometimes used as covers by political parties and their members. This was true especially of illegal political parties, which could not have their own premises and faced substantial difficulties in holding reunions. ${ }^{52}$ The choice of civil society, rather than political party, activism also offered a limited protection from the regime, given the deniability of the political nature of one's involvement. Such protection was awarded especially in organisations with larger membership that contained also pro-regime and non-partisan members.

The different types of more critical CSOs operated in very different ways, however. Advocacy CSOs possessed a strong network of political opponents around the country, with often overlapping institutional membership, that mobilised in support of the various victims of the regime, provided them with legal support, and documented and publicised their cases to expose the non-democratic nature of the regime's practices. To this end, they regularly issued communiqués and published thematic reports. The organisations' members also actively fostered contacts with foreign journalists, political representatives, and international human rights organisations, and drew attention to the specific issues in question by writing newspaper articles, participating in international conferences, or engaging in hunger strikes. Since all more critical CSOs operated in conditions of legal uncertainty, forging strong ties with international political actors, non-governmental organisations, and media was crucial not only for mounting sufficient 
pressure on the regime to soften its reaction in a specific case but also for obtaining a certain amount of protection from the regime for the organisation and its members in a type of a 'boomerang effect' (Keck and Sikkink 1998).

In contrast, unionist work tended to be more directly political. As the only widely available experience with mobilisation and politics in the country, the unions not only acted as important covers for political activities but also provided their members with valuable experience in collective claims-making, including negotiations with state authorities and the organisation of strikes and protests. Moreover, their presence around the country provided their members with an important resource that could be drawn upon for information, mobilization in response to specific issues, or as a source of recruitment for political parties and other CSOs. This was true especially for the UGTT, whose members often maintained close ties with UGET and UDC activists to both support and train them for their future membership in the union.

Finally, the activism of various professional organisations was political mostly indirectly, through their professional concerns that often clashed with the regime's authoritarian practices. As one oppositional journalist remarked, 'At the time, to be independent was to be an opponent. You were either with the regime or you were against. ${ }^{53}$ As a result, dissatisfied journalists, facing severe restrictions on freedom of expression, sometimes opted for alternative domestic or international publications and increasingly resorted to the internet or satellite TV and radio outlets, while oppositional lawyers chose to accept political cases. A significant number was also active in political parties or human rights and women's organisations and tried to push their respective professional organisations towards greater autonomy. However, many non-partisan members were also unhappy with the general state of their profession and the lack of responsiveness of the regime to their demands, which sometimes led to the election of 
more independent executive boards. Occupying the middle ground between human rights and women's organisations and general unions with regards to mobilisation potential and elite status, the organisations' actions were often symbolically important because of their professional identity.

\subsection{Supporting actors and bridge builders: Tunisian civil society during the revolution (17 December 2010 - 14 January 2011)}

Members of the more critical CSOs played a prominent role since the beginning of the protests that brought down the Ben Ali regime. ${ }^{54}$ On 17 December 2010, the first speech to the crowd gathering in Sidi Bouzid at the location of Mohamed Bouazizi's selfimmolation - an act that sparked the Tunisian revolution and captured the imagination of people throughout the MENA region - was reportedly given by a lawyer, who was a member of an illegal leftist political party, and trade union members accompanied the injured man and his family to the hospital and helped them deal with the authorities. ${ }^{55}$

Solidarity protests, which erupted the following day, developed a dual nature each with different types of participants - after the security forces encircled Sidi Bouzid and strengthened their presence in the city. ${ }^{56}$ More peaceful, organised marches, which took place during the day, had a broad attendance by all segments of the society. They were led mostly by local civil society activists, who not only contributed slogans, but also addressed the crowd. Local UGTT offices often presented the starting points of the day-time protests as its members made the union's physical as well as organisational resources available for protests. More violent confrontations with the police took place at night. They were led largely by young men from popular neighbourhoods who drew on their experience with confronting the police in football stadiums and universities. Although the two forms of protest were mostly independent, their participants regularly exchanged information. ${ }^{57}$ Similar scenes repeated themselves also in other interior 
regions, until the protests hit the more well-off coast, which was traditionally aligned with the regime. Throughout this time, the various civil society activists - like many regular Tunisians - made use of their pre-existing networks to obtain information about events around the country and subsequently spread the news both at home and abroad. However, the role of the individual CSOs was both more limited and more ambiguous. ${ }^{58}$ The end of December witnessed the first mobilisation efforts by lawyers and trade unionists in the capital, but they remained limited to a few dozen individuals and were thus easily contained by the police. ${ }^{59}$ Similarly, although individual UGTT members actively participated in the protests and local UGTT structures opened their offices, helped negotiate releases of detained protesters, and acted as mediators between the protesters and the regime, the union's leadership retained a cautious, pro-regime rhetoric. ${ }^{60}$ However, following substantial pressure by various local, regional, and federal sections, on 11 January 2011, UGTT leadership publicly denounced the regime's use of live ammunition against protesters and, shying away from calling for nation-wide action, gave the regional and sectoral committees the right to declare their own strikes. ${ }^{61}$ The UGTT strike in the capital, which coincided with the general strike of the lawyers, took place on 14 January 2011, two days after the watershed mass protests in Sfax, the industrial centre of Tunisia. The two types of actors joined forces in the morning, when the crowd gathered in front of the UGTT headquarters headed towards the main avenue, where a group of oppositional lawyers was demanding the release of an illegal communist party leader in front of the Ministry of Interior. ${ }^{62}$ They were then joined there by thousands of others Tunisians, who filled the city centre, calling for the President to leave. To everyone's surprise, this happened later in the day, ushering in a political transition that eventually resulted in democratic governance, even if it failed to resolve many of the underlying causes of the popular uprising. 
Ultimately, however, the social mobilisation that led to the fall of the Ben Ali regime was neither started nor driven by civil society actors. That was done by the thousands of Tunisians who were not previously active in politics or civil society and whose criticism of the regime had, until then, remained largely in the private sphere, limited to expressions of everyday frustrations, occasional disagreement, and scattered oppositional utterances within a trusted circle. During the days of the revolution, they came together - politicised by the regime's authoritarian practices and reactions to the ongoing protests - to form loose networks calling for political and socio-economic change. Meanwhile, the different types of more independent CSOs and their members participated in the revolution in mostly the same capacity as they have during previous individual and collective challenges to the regime, capitalizing on their strengths and suffering from the same shortcomings as before the revolution. Organisations with small partisan membership and weak support base in the society - like human rights and women's associations, as well as student and unemployed graduates unions - acted by mobilizing their pre-existing networks to obtain and spread information and offering their particular skills, connections, and expertise both during and outside of the protests. Organisations with broader membership and presence of members that were nonpartisan or loyal to the regime - like the general labour union or the various professional associations - sometimes mobilised, but they were constrained in their actions by internal struggles for control and oscillated between more conciliatory and confrontational positions, as well as pragmatic concerns about the necessity of maintaining a working relationship with the regime. Both were important in supporting the protests and helping them maintain their momentum through the actions and initiatives of their members, but they did not drive the political change nor could they bring it about on their own. 


\subsection{Tides of political change: Tunisian civil society after the revolution (2011 - present)}

In the aftermath of the revolution, Tunisia witnessed a substantial increase in CSOs (see Figure 1 above). In the first two years alone, almost 5,000 new associations were created, most related to charity, culture and arts, and development (Foundation for the Future 2013). The boom in new associations was driven by genuine citizen enthusiasm for civil society activism but also by the availability of foreign funding that provided an alternative to unemployment for many, especially younger, Tunisians. The postrevolutionary period also saw the emergence of a large number of social movements ${ }^{63}$ and informal, horizontally organised single issue campaigns mobilizing in response to specific political developments. ${ }^{64}$

In the new political context, new actors thrived, while many of the older, statealigned organisations like the UNFT struggled to redefine their role and ward off pressure to disband. ${ }^{65}$ Criticism for compromising positions during and prior to the revolution notwithstanding ${ }^{66}$ the established CSOs with a history of political opposition played a crucial role during the political transition, presenting important alternatives to political actors. This was the case especially in the early stages, as they possessed both the experience and the necessary organisational structures. In February 2011, 28 political parties and CSOs came together to form the 'National Council for the Protection of the Revolution', although the CNLT, ATFD, SNJT, and LTDH subsequently withdrew due to a preference for a consultative rather than a de facto government role (ICG 2011: 13-14). In March, the body, which included the UGTT and ONAT, was merged with the 'High Commission for Political Reform' to form the 'Higher Authority for the Realization of the Objectives of the Revolution, Political Reform, and the Democratic Transition', that was expanded and authorised to examine 
legislation, propose reforms, and express their view on the activities of the government. ${ }^{67}$

However, the directly political role of CSOs was short-lived. After the election of the National Constituent Assembly in October 2011, much of the political activity of civil society shifted into actively participating in the constitution drafting process.

During this time, important debates and mobilizations, which took place around controversial issues such as the status of women or the role of religion in the state, were shaped not only by established organisations like the ATFD but also by a large number of new civil society actors. The religious-secular polarisation - although at least partly politically instrumentalised - played itself out between secular and Islamist women's groups (Charrad and Zarrugh 2014; Khalil 2014), but significant divisions emerged also among the secular CSOs themselves, most notably between those active during the authoritarian period and those whose activism started during and after the revolution (Weilandt 2019). The role of the more critical CSOs from the Ben Ali period, however, did not wane. Instead, they continued to drive political change in the country, capitalizing not only on their experience but also on their expertise and symbolic importance. In particular, they successfully mediated the political crisis in 2013 and further maintained their dominant position on a multitude of political issues thereafter. This stands in contrast to many new CSOs struggling to move beyond their original project, professionalise, or secure funding. ${ }^{68}$

The different types of more critical CSOs have not been able to do this to the same degree, however. While several of the younger, previously illegal or repressed organisations like the ALTT or UDC were able to reach fuller potential after the revolution, ${ }^{69}$ many of the older CSOs lost prominent members or saw their membership decrease as new avenues for political and civil society activism became available. 
Although human rights and women's organisations were largely able to maintain their prominent positions by focusing on their specialised knowledge, the general unions have been struggling with massive decreases in membership and internal demands to focus more exclusively on professional rather than political issues. The internal struggles, reminiscent of the authoritarian period, did not render them unimportant, but weakened their role as political actors. Not facing the same types of pressure, professional associations and their members, significantly politicised both by the revolution and during the transition period, mostly struggle to refrain from taking positions that interfere with an impartial conduct of their profession. ${ }^{70}$ Together with the other political and civil society actors, the three types of more critical CSOs continue to present a thriving force in a nascent democratic society.

\section{Conclusion}

The political role of civil society under authoritarian rule and during democratic transitions is ambiguous and complex. Neither is civil society generally a prodemocracy force, nor can particular CSOs, or types of CSOs, be a priori categorised as vehicles of regime control or agents of opposition and change. As the discussion of the political role of CSOs before, during, and after the revolution in Tunisia shows, the political context, the type of CSO, the history, experience, and symbolic status of any particular $\mathrm{CSO}$, and the interaction with both the regime and other political actors matter in explaining the size, political orientation, and mobilizing potential of civil society for or against the regime.

Before the revolution, the ability of CSOs to challenge the regime was limited and the Ben Ali regime was able to not only successfully manage the Tunisian civil society through a repressive legal framework and a mix of coercive and co-optative measures but also use CSOs to increase its resilience and pursue its political objectives. 
The handful of more critical and independent CSOs were, nonetheless, able to help maintain opposition in the authoritarian context and provide their members with the space, resources, and experience in confronting the regime, crucial for their subsequent role in the revolution and the country's democratic transition. During the revolution, these organisations were able to play an important supporting role, primarily through their members, who helped to frame and politicise the movement, negotiate with the regime on the protesters' behalf, and coordinate between the different protest actors. They also communicated with international media, political, and civil society actors and activated their networks to obtain and spread information. The changed political context in the post-revolutionary period allowed these organisations to transform into essential political actors that helped to drive and steer the democratization process in the country. They were able to play this role not only because they enjoyed substantial symbolic capital for acting as rare voices of opposition to the Ben Ali regime and as prominent actors during the revolution, but also because they had the necessary level of organisation, prior networks, experience in dealing with state authorities, and expertise to engage with the transitional issues at hand. Further, the analysis illustrates that distinguishing the type of CSOs provides a more nuanced understanding of the role of civil society in different political phases and contexts. Human rights and women's organisations are best positioned to produce political elites, unions command over the most significant mobilizing potential, and professional associations are the basis for the proper democratic functioning of the state.

Overall, the Tunisian case shows that civil society is neither a silver bullet against authoritarianism nor an unequivocal force for good. In the pre-revolutionary period, the Tunisian civil society, including its more critical elements, helped maintain the regime, tacitly supported some of its authoritarian policies, and occasionally 
engaged in non-democratic behaviour. Even in the post-revolutionary context, when civil society played a crucial role in the country's successful transition to democracy, it also contributed to the polarisation of the society and marginalisation of some actors. Scholars as well as policy practitioners should thus be realistic about what civil society in authoritarian - as well as newly democratic - context is and what it can reasonably achieve. However, the Tunisian experience also demonstrates that, during the authoritarian phase, the more critical CSOs can serve as rare islands of political resistance, helping to maintain visible protest, and act as important schools of activism and mobilisation that shelter, connect, and form future political actors. This will not bring down authoritarian regimes, but can be essential during pro-democracy protests as well as the subsequent political transition.

\section{References}

Armony, Ariel. 2004. The Dubious Link: Civic Engagement and Democratization. Stanford: Stanford University Press.

Allal, Amin. 2008. "Réformes néolibérales, clientélismes et protestations en situation autoritaire. Les mouvements contestataires dans le bassin minier de Gafsa en Tunisie (2008)." Politique africaine 117 (1): 107-125.

Alexander, Christopher. 1997. "Back from the Democratic Brink: Authoritarianism and Civil Society in Tunisia.” Middle East Report 205: 34-38.

Antonakis-Nashif, Anna. 2016. "Contested Transformation: Mobilized Publics in Tunisia between Compliance and Protest.” Mediterranean Politics 21 (1): 128149.

Beissinger, Mark. 2017. “'Conventional' and 'Virtual' Civil Societies in Autocratic Regimes." Comparative Politics 49 (3): 351-371.

Berman, Sheri. 1997. "Civil Society and the Collapse of the Weimar Republic." World Politics 49 (3): 401-429.

Bernhard, Michael. 1993. "Civil Society and Democratic Transition in East Central Europe." Political Science Quarterly 108 (2): 307-326. 
Carothers, Thomas. 1999. Aiding Democracy Abroad: The Learning Curve. Washington: Brookings Institution Press.

Challand, Benoit. 2011. "The Counter-Power of Civil Society and the Emergence of a New Political Imaginary in the Arab World.” Constellations 18 (3): 271-283. Charrad, Mounira, and Amina Zarrugh. 2014. "Equal or Complementary? Women in the New Tunisian Constitution after the Arab Spring." The Journal of North African Studies 19 (2): 230-243.

Chouikha, Larbi, and Vincent Geisser. 2010. "Retour sur la révolte du bassin minier. Les cinq leçons politiques d'un conflit social inédit.” L'Année du Maghreb VI: 415-426.

Chouikha, Larbi, and Éric Gobe. 2009. "Les organisations de défense des droits de l'Homme dans la formule politique tunisienne: acteurs de l'opposition ou fairevaloir du régime?" L'Année du Maghreb V: 163-182.

Clark, Janine. 2013. "Relations between professional associations and the state in Jordan.” In Civil Society Activism under Authoritarian Rule: A comparative perspective, edited by Francesco Cavatorta, 158-180. London: Routledge.

Committee to Protect Journalists. 2009. "Naziha Réjiba, Tunisia, Kalima: International Press Freedom Awards.” https://cpj.org/awards/2009/naziha-rejiba-editorkalima.php.

Diamond, Larry. 1994. "Rethinking Civil Society: Toward Democratic Consolidation." Journal of Democracy 5 (3): 4-17.

Doyle, Jessica. 2016. “Civil Society as Ideology in the Middle East: A Critical Perspective.” British Journal of Middle Eastern Studies 43 (3): 403-422.

Durac, Vincent, and Francesco Cavatorta. 2009. "Strengthening Authoritarian Rule through Democracy Promotion? Examining the Paradox of the US and EU Security Strategies: The Case of Bin Ali's Tunisia." British Journal of Middle Eastern Studies 36 (1): 3-19.

Encarnación, Omar. 2003. The Myth of Civil Society: Social Capital and Democratic Consolidation in Spain and Brazil. New York: Palgrave Macmillan.

Fishman, Robert. 2017. "How Civil Society Matters in Democratization: Setting the Boundaries of Post-Transition Political Inclusion.” Comparative Politics 49 (3): 391-409.

Folley, Michael, and Bob Edwards. 1996. "The Paradox of Civil Society.” Journal of Democracy 7 (3): 38-52. 
Forment, Carlos. 2003. Democracy in Latin America: Civic Selfhood and Public Life in Mexico and Peru, 1760-1900. Chicago: University of Chicago Press.

Foundation for the Future. 2013. "Study on Civil Society Organizations in Tunisia." http://foundationforfuture.org/en/Portals/0/Publications/Etude \%20SC\%20englis $\underline{\mathrm{h} \% 20 \text { Version } \% 20 \text { Finale.pdf. }}$

Freedom House. 2015. "Freedom in the World 2015: Discarding Democracy: A Return to the Iron Fist." https://freedomhouse.org/sites/default/files/01152015_FIW 2015 final.pdf.

Geyer, Georgie. 1998. “Tunisia: A country that works.” The Washington Quarterly 21 (4): 93-106.

Gobe, Éric. 2010. "The Tunisian Bar to the test of authoritarianism: professional and political movements in Ben Ali's Tunisia (1990-2007)." The Journal of North African Studies 15 (3): 333-347.

Gobe, Éric. 2013. Les avocats en Tunisie de la colonisation à la révolution (18832011): sociohistoire d'une profession politique. Paris: Karthala.

Gobe, Éric, and Michaël Béchir Ayari. 2007. "Les avocats dans la Tunisie de Ben Ali: une profession politisée?" L'Année du Maghreb III: 105-132.

Grugel, Jean. 2000. "Romancing Civil Society: European NGOs in Latin America." Journal of Inter-American Studies and World Affairs 42 (2): 87-107.

Hadenius, Axel, and Fredrik Uggla. 1996. "Making Civil Society Work, Promoting Democratic Development: What Can States and Donors Do?" World Development 24 (10): 1621-1639.

Heydemann, Steven. 2007. Upgrading Authoritarianism in the Arab world. Analysis paper 13. Washington, DC: Saban Center for Middle East Policy at the Brookings Institution.

http://www.brookings.edu/ /media/research/files/papers/2007/10/arabworld/10a rabworld.pdf.

Hibou, Béatrice. 2011. The Force of Obedience: The Political Economy of Repression in Tunisia. London: Polity Press.

Howard, Marc. 2003. The Weakness of Civil Society in Post-Communist Europe. Cambridge: Cambridge University Press.

Hsu, Carolyn. 2010. "Beyond Civil Society: An Organizational Perspective on StateNGO Relations in the People's Republic of China." Journal of Civil Society 6 (3): 259-277. 
Huntington, Samuel. 1991. The Third Wave: Democratization in the Late Twentieth Century. Norman: Oklahoma University Press.

International Crisis Group (ICG). 2011 "Popular Protest in North Africa and the Middle East (IV): Tunisia’s Way.” Middle East/North Africa Report No. 106.

https://www.crisisgroup.org/middle-east-north-africa/north-

africa/tunisia/popular-protests-north-africa-and-middle-east-iv-tunisia-s-way.

Keck, Margaret, and Kathryn Sikkink. 1998. Activists Beyond Borders: Advocacy

Networks in International Politics. Ithaca: Cornell University Press.

Khalil, Andrea. 2014. "Tunisia's women: Partners in Revolution.” The Journal of North African Studies 19 (2): 186-199.

Kotkin, Stephen. 2010. Uncivil Society: 1989 and the Implosion of the Communist Establishment. New York: Random House.

Langohr, Vickie. 2004. “Too Much Civil Society, Too Little Politics: Egypt and Liberalizing Arab Regimes." Comparative Politics 36 (2): 181-204.

Linz, Juan, and Alfred Stepan. 1996. "Toward Consolidated Democracies.” Journal of Democracy 7 (2): 14-33.

Lewis, David. 2013. "Civil Society and the Authoritarian State: Cooperation, Contestation and Discourse." Journal of Civil Society 9 (3): 325-340.

Mabrouk, Mehdi. 2011. “A Revolution for Dignity and Freedom: Preliminary Observations on the Social and Cultural Background to the Tunisian Revolution." The Journal of North African Studies 16 (4): 625-635.

Michnik, Adam. 1985. Letters from Prison and Other Essays. Berkeley: University of California Press.

Norwegian Nobel Committee. 2015. “The Nobel Peace Prize for 2015.” Press release. https://www.nobelprize.org/nobel_prizes/peace/laureates/2015/press.html. O’Donnell, Guillermo, and Philippe Schmitter. 1986. Transitions from Authoritarian Rule: Tentative Conclusions about Uncertain Democracies. Baltimore: Johns Hopkins University Press.

Pikulik, Alexei, and Sophie Bedford. 2019. “Aid Paradox: Strengthening Belarusian Non-democracy through Democracy Promotion." East European Politics and Societies and Cultures 33 (2): 378-399.

Powel, Brieg. 2009. "The stability syndrome: US and EU democracy promotion in Tunisia." The Journal of North African Studies 14 (1): 57-73. 
Putnam, Robert. 1993. Making Democracy Work: Civic Traditions in Modern Italy. Princeton: Princeton University Press.

Putnam, Robert. 2000. Bowling Alone: The Collapse and Revival of American

Community. New York: Simon \& Schuster.

Rahman, Maha. 2002. "The Politics of 'Uncivil' Society in Egypt." Review of African Political Economy 29 (91): 21-35.

Ruzza, Carlo. 2009. "Populism and Euroscepticism: Towards Uncivil Society?" Policy and Society 28 (1): 87-98.

Repnikova, Maria. 2018. "Contesting the State under Authoritarianism: Critical Journalists in China and Russia." Comparative Politics 51 (1): 41-60.

Schlumberger, Oliver. 2000. "The Arab Middle East and the Question of Democratization: Some Critical Remarks." Democratization 7 (4): 104-132.

Spires, Anthony. 2011. "Contingent symbiosis and civil society in an authoritarian state: Understanding the survival of China's grassroots NGOs." American Journal of Sociology 117 (1): 1-45.

Tempest, Clive. 1997. "Myths from Eastern Europe and the legends of the West." Democratization 4 (1): 132-144.

de Tocqueville, Alexis. 1835. Democracy in America.

United Nations Development Programme (UNDP). 2014. "La société civile dans une Tunisie en mutation." http://touensa.org/wp-content/uploads/2014/07/Lasoci $\% \mathrm{C} 3 \% \mathrm{~A} 9 \mathrm{t} \% \mathrm{C} 3 \% \mathrm{~A} 9-$ civile-dans-une-Tunisie-en-mutation.pdf.

Weilandt, Ragnar. 2019. "Divisions within Post-2011 Tunisia's Secular Civil Society." Democratisation 26 (6): 959-974.

Wiktorowicz, Quintan. 2000. "Civil Society as Social Control: State Power in Jordan.” Comparative Politics 33 (1): 43-61.

Yom, Sean. 2005. "Civil Society and Democratization in The Arab World." Middle East Review of International Affairs 9 (4): 14-33.

Yousfi, Hèla. 2015. L'UGTT, une passion tunisienne. Enquête sur les syndicalistes en révolution 2011-2014, Tunis: Med Ali Editions - Institut de recherche sur le Maghreb contemporain (IRMC).

Ziegler, Charles. 2010. "Civil society, Political Stability, and State Power in Central Asia: Cooperation and Contestation.” Democratization 17 (5): 795-825. 


\section{Notes}

${ }^{1}$ The fourth organisation, Tunisian Union of Industry, Trade, and Handicrafts (Union tunisienne de l'industrie, du commerce et de l'artisanat, UTICA), was historically close to the Ben Ali regime and invited to participate in the initiative to achieve greater inclusiveness and representation as earlier unilateral attempts by UGTT to launch a 'National Dialogue' process were unsuccessful.

${ }^{2}$ Informal social groups and social movements, as well as political parties, which are also occasionally considered part of civil society, are excluded here to avoid generating a catch-all category that encompasses virtually any form of collective action.

${ }^{3}$ Density of about 1 association for 1,000 inhabitants.

${ }^{4}$ Organic law no. 88-90 of 2 August 1988.

${ }^{5}$ Organic law no. 92-25 of 2 April 1992.

${ }^{6}$ For an overview of the situation 10 years after Ben Ali took power, as well as a comparison with the regime of Habib Bourguiba, see Alexander (1997).

${ }^{7}$ See for example Geyer (1998).

${ }^{8}$ Law no. 59-154 of 7 November 1959, as modified by Organic law no. 88-90 and Organic law no. $92-25$.

${ }^{9}$ Upon the publication of the association's details in the Official Journal of the Tunisian Republic.

${ }^{10}$ Organic law no. 92-25.

${ }^{11}$ Article 8 of law no. $59-154$.

${ }^{12}$ Organic law no. 92-25.

${ }^{13}$ Law no. 69-4 of 24 January 1969 regulating public meetings, processions, parades, demonstrations and gatherings, but public authorities also regularly evoked other regulations.

${ }^{14}$ Law no. $2010-35$ of 29 June 2010 amending Article 61bis of the Tunisian Penal Code.

${ }^{15}$ Interviews with oppositional civil society activists, Tunisia, 2014-2016.

${ }^{16}$ See for example Gobe (2013).

${ }^{17}$ Members of CSOs could also be chosen to fill the seats nominated directly by Ben Ali (Constitutional act no. 2002-51 of 1 June 2002).

${ }^{18}$ The fund, also known as '26-26', was infamous for its abuse by the Ben Ali family. For more information, see Hibou (2011).

${ }^{19}$ Chapter II of Law no. 59-154.

${ }^{20}$ Interviews with ATFD members, Tunis, April 2016. The sentiment was also echoed by many UGET and UGTT members, especially those in extreme left political parties. 
${ }^{21}$ Amnesty International and Arab Institute for Human Rights operated also in Tunisia.

${ }^{22}$ Interview, Gafsa, March 2015.

${ }^{23}$ This is in line with developments in many other Arab countries (Langohr 2004).

${ }^{24}$ Interview, Tunis, April 2016.

${ }^{25}$ Ibid.

${ }^{26}$ Interview with Mondher Cherni, Vice-President of ALTT, Tunis, June 2015.

${ }^{27}$ For an overview of the role of human rights organisations in Tunisia, see Chouikha and Gobe (2009).

${ }^{28}$ ATFD had about 150-200 members (Interview with ATFD executive committee member, Tunis, June 2015).

${ }^{29}$ Interviews with senior ATFD members, Tunis, May-June 2015.

${ }^{30}$ Ibid.

${ }^{31}$ Interview, Tunis, December 2014.

${ }^{32}$ Interview with a national UGTT representative, Tunis, April 2016.

${ }^{33}$ Estimate provided by an active unionist and illegal extreme left political party member (Interview, Gafsa, March 2015).

${ }^{34}$ Point re-iterated also by many civil society and political activists.

${ }^{35}$ More 'rebellious' sections - like the primary and secondary education, health, and postal services sections, as well as some regional unions - often had a higher number of oppositional political party members also at higher organisational levels (Interviews with UGTT members, Tunisia, 2014-2016).

${ }^{36}$ Ibid.

${ }^{37}$ Interviews with former UGET activist, Gafsa, April 2015.

${ }^{38}$ Interviews with former UGET activists from Tunis, Gafsa, Bizerte, Kairouan, and Sousse, 2014-2015.

${ }^{39}$ Ibid.

${ }^{40}$ Previous attempts to establish the organisation took place in late 1990s and early 2000s (Interview with UDC executive committee member, Tunis, July 2015).

${ }^{41}$ Interviews with UDC activists, Gafsa and Tunis, March-July 2015.

${ }^{42}$ Ibid.

${ }^{43}$ For an analysis of the lawyers as a profession and their political role prior to the revolution, see Gobe $(2010,2013)$ and Gobe and Ayari (2007).

${ }^{44}$ Ibid.

${ }^{45}$ Interview with an oppositional lawyer, Tunis, June 2015.

${ }^{46}$ Ibid.

${ }^{47}$ Estimate provided by Tunisian media sociologist Riadh Ferjani (Interview, Tunis, November 2014). 
${ }^{48}$ Interviews with oppositional journalists and senior SJT members, Tunis, June 2015.

${ }^{49}$ Ibid.

${ }^{50}$ Interview with prominent anti-regime judge Mokhtar Yahyaoui, Tunis, June 2015.

${ }^{51}$ Ibid.

${ }^{52}$ Interviews with illegal political party members, Tunisia, 2014-2016.

${ }^{53}$ Interview, Tunis, June 2015.

${ }^{54}$ This is not to say that they initiated the revolution or comprised most of its supporters.

According to the 2011 Arab Barometer, only a little over one fifth of those who participated in the revolution were members of CSOs (Beissinger 2017, 363). On the sequencing and underlying causes of the revolution, see for example Mabrouk (2011) and ICG (2011).

${ }^{55}$ Interviews with the lawyer and several UGTT members, Sidi Bouzid, May 2015.

${ }^{56}$ Interviews with protest participants, Sidi Bouzid, May 2015.

${ }^{57}$ Ibid.

${ }^{58}$ See also Mabrouk (2011).

${ }^{59}$ Interviews with participants, Tunis, 2014-2016.

${ }^{60}$ For more information, see Yousfi (2015).

${ }^{61}$ Interview with a national UGTT representative, Tunis, April 2016.

${ }^{62}$ Interviews with participants from both groups, Tunis, 2014-2016.

${ }^{63}$ Monthly overviews of social movement developments are provided by the Tunisian Forum for Economic and Social Rights (Forum tunisien pour les droits économiques et sociaux, FTDES).

${ }^{64}$ A prominent example is the Manish Msameh (I will not forgive) movement, which opposed economically motivated amnesty for former regime officials and business elites.

${ }^{65}$ Interview with UNFT president, Tunis, April 2016.

${ }^{66}$ This was true especially for the UGTT, which faced vigorous attacks for trying to 'hijack' the revolution and derail the transition (Yousfi 2015).

${ }^{67}$ Decree-law no. 2011-6 of 18 February 2011. For more information about CSO involvement during the transitional period, see for example Antonakis-Nashif (2016).

${ }^{68}$ Interviews with activists from smaller CSOs, Tunis, April 2016.

${ }^{69}$ The former as Organisation Against Torture in Tunisia (Organisation contre la torture en Tunisie, OCTT).

${ }^{70}$ This seems to be the case especially for journalists (Interviews with former oppositional journalists and representatives of international CSOs, Tunis, April 2016). 